研究発表論文

\title{
神奈川県逗子市新宿地区における緑被の推移に関する研究
}

\section{A Study on the Change of Green Coverage at Zushi City, Kanagawa}

\author{
近江慶光 ${ }^{*}$ 丸田頼一* \\ Yoshimitsu OMI Yorikazu MARUTA
}

摘要：神奈川県逗子市新宿地区において，住居系市街地における緑被の保全について検討するための

基礎資料を得ることを目的に研究を行った。そこでまず 1940 年代から現在までの空中写真をもとに

緑被を抽出し，さらに緑被の推移の特徽を明らかにした。その結果，敷地の細分化が緑被の隇少をも

たらすこと，一般住宅から集合住宅への建筑形態の変化や観光・レクリェーション・リソート施設等

の商業施設への転用が緑被の大きな消隇をもたらしていることが把握された。したがって今後，敷地 改変に対する制限や都市計画上の用途地域指定変更に伴う土地利用規制等を加えるとともに，開発行 為の際における緑被の保全・緑化を強化する施策の必要があると考えられる。

\section{1. 研究の背景および目的}

住居系市街地では都市化の進展にともない緑の著しい減少，居 住環境の低下といった問題が起きてきており，環境保全の在り方 を検討する必要性が生じてきている。

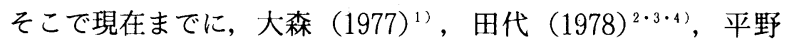
$(1979)^{5)}$, 高見 $(1979)^{6)}$ ら多くの研究が行われてきている。

筆者らむ敷地の細分化之緑の減少との関係について研究を行っ てきており，その結果，敷地面積や空地面積をある程度確保する ことが必要であることが明らかとなってきている。?

本研究は, 住居系市街地における緑被の保全について検討する ための基礎資料を得ることを目的とし，住宅地整備と緑被との時 系列的関連性を探るのに好例と考えられる, 神奈川県逗子市新宿 地区において，緑被の推移の特徵と敷地の変化等を明らかにしよ うとするものである。本調查地を研究することにより, 約 50 年 間にわたる变遷が把握できるのみならず，首都圈近郊都市や沿岸 域等の別荘地加住居系市街地への発展に係わる諸資料や緑被に 係わる対策の方向性も把握できることになる。

\section{2. 研究の方法}

\section{（1）調查地の選定}

本研究の調査地である神奈川県逗子市新宿地区は図 -1 に示し たとおり，逗子海岸に接している。

また新宿 1 丁目はかつて別荘地として開発された歴史的経緯を 有し, 1940 年に住居地域の指定を受け, 今日に至っている。

\section{(2) 調查方法}

緑被の推移および敷地の細分化の状況, 土地利用の変化を把握 するために, 1946 年, 1963 年, 1977 年, 1988 年, 1992 年の国 土地理院撮影の空中写真（4 倍引き延ばし）を基に解析を行った。 縮尺は年によって異なったが約 2500 分の 1 であった。

空中写真を判読することにより，植栽状況や敷地境界，土地利 用, 建築形態が把握可能である。

まず，空中写真判読より本調査地には農地が存在しなかったこ とがわかった。また, 明確に認識できる芝生等草地は存在せず, そこで緑被はすべて樹木と考えられた。

そこで, 空中写真から樹冠投影面積を測定し, 敷地面積に対す る樹冠投影面積の割合を緑被率として算出し，その推移を把握し た。
また, 各年代別の空中写真と 1989 年の都市計画基本図より, 敷地の細分化の状況および土地利用について把握した。

3. 結果および考察

（1）年代別緑被等の状況
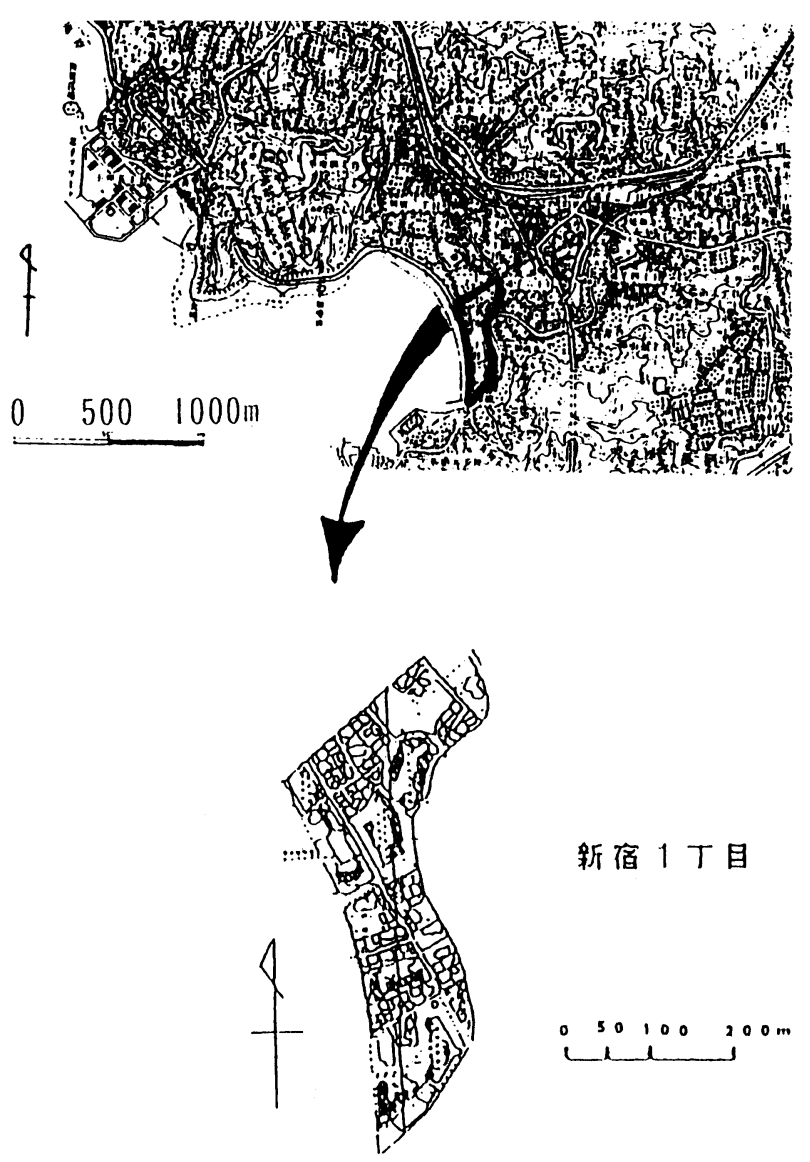

図一 1 調查地

*千葉大学園芸学部 


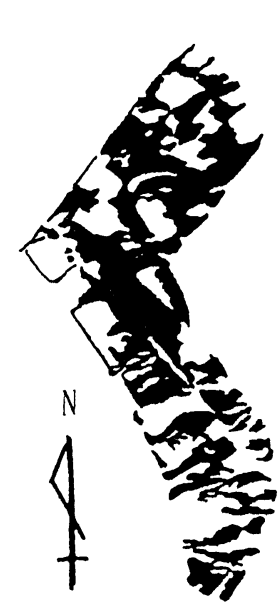

1946 年
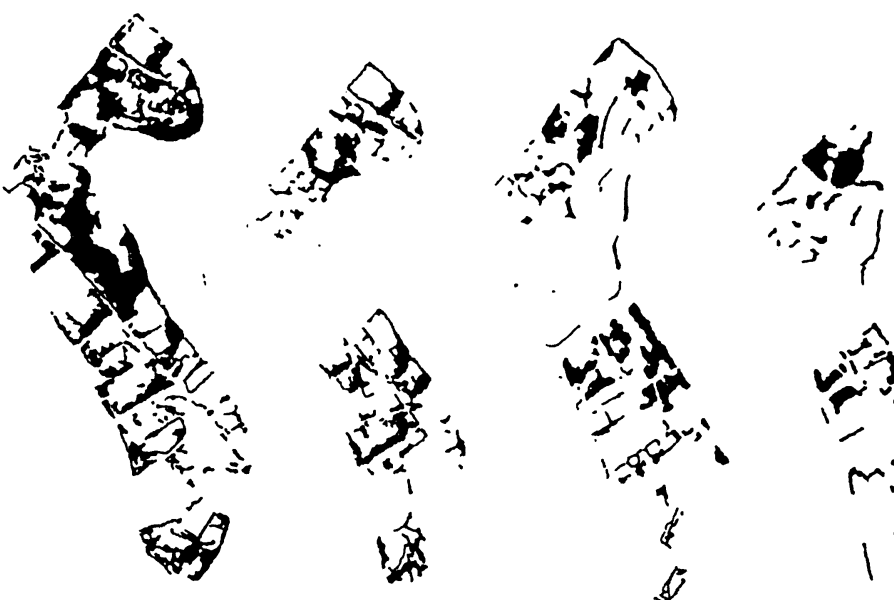

1977年
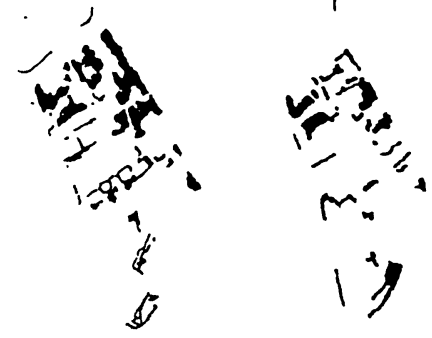

1988年

1992年

図－２緑被の推移

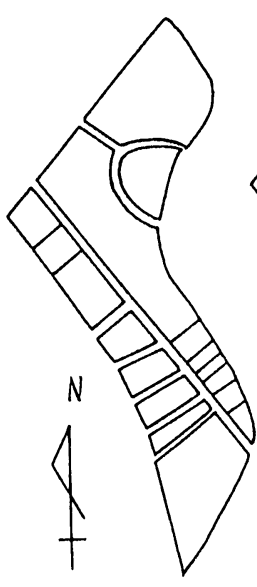

1946 年

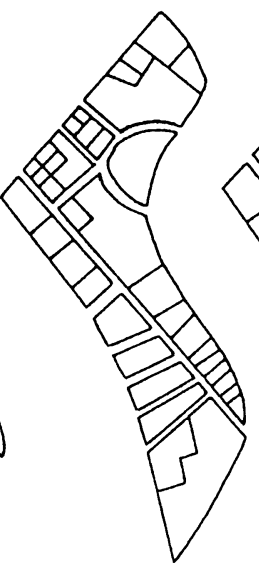

1963 年

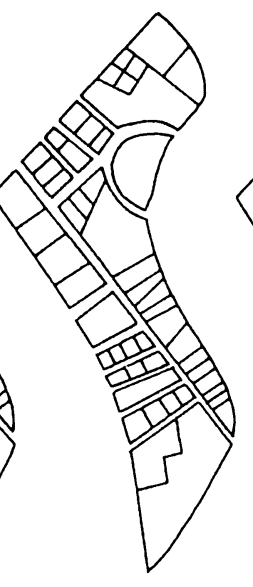

1977年

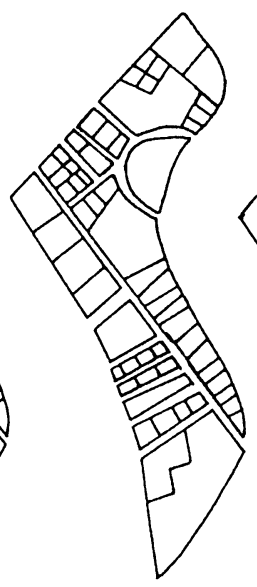

1988年



1992 年

$0 \quad 100 \quad 200 \mathrm{~m}$

図ー 3 敷地の推移

各年代の空中写真より抽出した緑被は図ー 2 に示したとおりで ある。

（i） 1946 年当時の状況

国道 134 号線（湘南道路）は 1964 年に整備されたため, 1946 年当時には存在していない。

空中写真判読により海岸沿いには敷地面積が $400 \mathrm{~m}^{2}$ を越える比 較的敷地規模の大きな別荘地が連なっていることがわかった。

また各敷地の境界部には樹林地が存在しており, 当時の緑被率 は $55.7 \%$ でった。

（ii） 1963 年当時の状況

1946 年よりこの間の空中写真が入手できなかったため, 17 年
後の様子である。

戦後, 別荘地の所有者には重税がかけられ，神奈川県藤沢市鵠 沼地区や千葉県一の宮町などといった別荘地では, 戦後急速に大 規模な別荘地の細分化が起こり，緑被の減少が進んだ時期であ $3^{7)}$ 。

本調查地においても敷地内に樹木の存在しない敷地が出現し， 1963 年当時の緑被率は $37.7 \%$ に減少している。

（iii） 1977 年当時の状況

敷地の細分化が進むとともに, 土地利用の変化が起こりはじめ る。調查地の中央部分で大きく緑被が消隇している様子が図 -2 からわかる。緑被率は $18.8 \%$ と 1963 年からの 14 年間で半減し 
表ー 1 年代別にみた敷地の細分化・土地利用と敷地内の 樹木の現状

\begin{tabular}{|c|c|c|c|c|c|}
\hline \multicolumn{5}{|c|}{ 年代別にみた敷地の細分化・土地利用 } & \multirow[t]{2}{*}{$\begin{array}{l}\text { 敷地内に扔ける樹木 } \\
\text { の現状 }\end{array}$} \\
\hline 1946年 & 1963年 & 1977年 & 1988年 & 1992年 & \\
\hline \multirow[t]{11}{*}{11626} & \multirow[t]{2}{*}{2534} & \multirow[t]{2}{*}{2534} & \multirow[t]{2}{*}{2534} & 1656 & 無 \\
\hline & & & & 878 & 無 \\
\hline & 1315 & 1315 & 1315 & 1315 & 無 \\
\hline & \multirow[t]{2}{*}{819} & 448 & 448 & 448 & 無 \\
\hline & & 371 & 371 & 371 & 無 \\
\hline & \multirow[t]{2}{*}{644} & 305 & 305 & 305 & 有 \\
\hline & & 339 & 339 & 339 & 有 \\
\hline & \multirow[t]{4}{*}{6314} & \multirow[t]{4}{*}{6314} & 384 & 384 & 無 \\
\hline & & & 299 & 299 & 無 \\
\hline & & & 299 & 299 & 與 \\
\hline & & & 5332 & 5332 & 有 \\
\hline \multirow[t]{22}{*}{13537} & 415 & 415 & 415 & 415 & 有 \\
\hline & 387 & 387 & 387 & 387 & 有 \\
\hline & 229 & 229 & 229 & 229 & 有 \\
\hline & \multirow[t]{3}{*}{1281} & 400 & 400 & 400 & 無 \\
\hline & & 710 & 710 & 710 & 有 \\
\hline & & 171 & 171 & 171 & 無 \\
\hline & \multirow[t]{7}{*}{1649} & \multirow[t]{2}{*}{523} & 268 & 268 & 無 \\
\hline & & & 255 & 255 & 無 \\
\hline & & \multirow[t]{2}{*}{471} & 148 & 148 & 無 \\
\hline & & & 323 & 323 & 無 \\
\hline & & 300 & 153 & 153 & 無 \\
\hline & & & 147 & 147 & 無 \\
\hline & & 355 & 355 & 355 & 無 \\
\hline & 395 & 395 & 395 & 395 & 無 \\
\hline & 579 & 579 & 579 & 192 & 無 \\
\hline & & & & 387 & 無 \\
\hline & 4990 & ** 4990 & $* * 4990$ & ** 4990 & 有(緑化されたもの) \\
\hline & 2601 & 2601 & 750 & 750 & 無 \\
\hline & & & 799 & 799 & 有 \\
\hline & & & 600 & 600 & 有 \\
\hline & & & 452 & 452 & 無 \\
\hline & 1011 & 1011 & 1011 & 1011 & 有 \\
\hline 735 & 368 & 368 & 368 & 368 & 有 \\
\hline & 367 & 367 & 367 & 367 & 有 \\
\hline 3203 & 1681 & ** 1681 & ** 1681 & ** 1681 & 無 \\
\hline & 1522 & ** 1522 & ** 1522 & ** 1522 & 無 \\
\hline 1566 & 740 & 107 & 107 & 107 & 有 \\
\hline & & 230 & 230 & 230 & 有 \\
\hline & & 229 & 229 & 229 & 有 \\
\hline & & 174 & 174 & 174 & 有 \\
\hline & 826 & 285 & 285 & 285 & 無 \\
\hline & & 229 & 229 & 229 & 無 \\
\hline & & 312 & 312 & 312 & 無 \\
\hline 1982 & 1982 & 274 & 274 & 274 & 無 \\
\hline & & 329 & 329 & 329 & 無 \\
\hline & & 582 & 582 & 582 & 無 \\
\hline & & 797 & 797 & 797 & 有 \\
\hline 11582 & * 2577 & * 2577 & *2577 & *2577 & 有 \\
\hline & *9005 & *9005 & *9005 & *9005 & 有(緑化されたもの) \\
\hline 3427 & 3427 & 3427 & 3427 & 3427 & 有(緑化されたもの) \\
\hline 794 & 794 & 794 & 794 & 794 & 有 \\
\hline 714 & 714 & 714 & 714 & 714 & 有 \\
\hline 463 & 463 & 463 & 463 & 463 & 有 \\
\hline 480 & 480 & 480 & 480 & 480 & 有 \\
\hline 511 & 511 & 511 & 511 & 511 & 有 \\
\hline 1613 & 1613 & 1613 & 1613 & 1613 & 無 \\
\hline 1680 & * 1680 & * 1680 & * 1680 & * 1680 & 無 \\
\hline 2506 & *2506 & *2506 & *2506 & *2506 & 有 \\
\hline 1675 & 1675 & 1675 & 1675 & 1675 & 有 \\
\hline
\end{tabular}

ている。

（iv） 1988 年当時の状況

緑被率は $23.7 \%$ と, 1977 年と比較すると增加している。

これは 1977 年当時樹木が伐採されて未利用地となっていた敷 地に，新たに集合住宅が建設され，それにともない緑化が行われ たためであると考えられる。

（v）1992 年当時の状況

緑被率は $17.2 \%$ となり, 1988 年と比較して若干の緑被の隇少
がみられる。空中写真からは古くからの敷地で建築物が取り壊さ れている場合が確認でき, 残存していた緑被がさらに減少してい るむのと考えられる。

\section{（2）敷地単位における樹木の存在の現状}

つぎに, 緑被の現状をより詳細に把握するために，1992 年の 空中写真を基に敷地毎に樹木の有無を調べた。その結果, 表一1 に示したとおり，60 敷地中 25 敷地 (41.7\%) の敷地に樹木が存 在していることがわかった。

\section{（3）敷地の細分化と土地利用の変遷}

敷地の細分化と土地利用の変化について空中写真を基にとらえ た。

1946 年の空中写真からは, 樹林に囲まれた別荘地が連なり, また砂浜には「海の家」が存在している様子が捉えられた。

1963 年の空中写真からは，海岸線沿いでは，功ての「海の 家」のような仮設の施設にかわり，近代的な観光産業の進出が起 き, 住居系から商業系へと土地利用が変化していることが把握で きた。

さらに, 1977 年の空中写真より, 敷地の細分化が進む様子が みられるが，これは 1964 年の国道 134 号線（湘南道路）整備に ともない, 別荘地から住宅供給地へと転換していったため, 細分 化が急激に進んだものと考えられる。

また宅地化・敷地の細分化が進む一方で，マリン・リゾートと しても発達しつつあり, 本調査地に隣接する田越川には多くのフ レジャー・ボートが停泊するようになり，またリゾートマンショ ンが建設された。

つぎに，各年代別の空中写真と 1989 年の都市計画基本図を基 に敷地境界を確定し，図ー3に示したように区画の变化を捉え， また表ー 1 に示したようにあわせて敷地面積, 土地利用, 敷地内 樹木の有無について調べた。

その結果, 1946 年 17 敷地であった敷地数は, 1963 年 34 敷地, 1977 年 49 敷地, 1988 年 58 敷地, 1992 年 60 敷地之変化してい ること，1946 年以降，区画に変化のない敷地は 10 敷地であるこ とがわかった。

土地利用の変化をみると, 1946 年から 1963 年の間に住居系か ら商業系に変化した敷地が 4 敷地，1963 年から 1977 年の間に 般住宅からリゾートマンションなどの中高層の集合住宅に変化し たものが 3 敷地存在したことがわかった。これらは敷地面積が $1500 \mathrm{~m}^{2}$ 越える大規模なものである。

一般住宅は 1992 年には 53 敷地存在し，このうち 45 敷地 （84.9\%）が細分化されたものであった。また敷地面積をみると， $1500 \mathrm{~m}^{2}$ 越える大規模な敷地が 4 敷地 (8.9\%) 存在する一方で, $400 \mathrm{~m}^{2}$ 以下の敷地は 27 敷地 $(60.0 \%)$ と，1946 年当時の最小敷 地面積である $463 \mathrm{~m}^{2}$ を回る住宅が過半数を占めていることがわ かった。

\section{(4) 総合考察}

1946 年以降に細分化された敷地のうち一般住宅は 45 敷地であ り，このうち樹木が存在しているものは 17 敷地 (37.8\%) であっ た。

一方, 1946 年以降, 区画の形状に变化のない敷地 10 敷地のう ち, 樹木が現存するものは 8 敷地であり, 一般住宅 7 敷地, 商業 施設 1 敷地であった。樹木が現存しなかった 2 敷地は, 1946 年 から 1963 年の間に住居系から商業系に土地利用が変化した敷地 であった。

また, 樹木が現存する 8 敷地中 7 敷地の一般住宅については 1946 年当時の樹木が残存しているすのであり, 商業施設の 1 敷 地に関しては住居系から商業系に土地利用が变化した際に伐採さ れ，その後緑化されて現在に至っているあのと把えた。

1963 年から 1977 年の間に一般住宅から中高層の集合住宅に変 
化したものについて，樹木の存在状況をみると 3 敷地中 1 敷地に 緑化がみられるが, これも集合住宅建設後に緑化されたあのであ る。

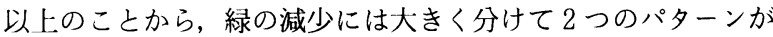

考えられる。

すなわち，敷地の細分化により，大きな緑被が細切れとなり， 減少するパターン。もう一つは敷地面積 $1500 \mathrm{~m}^{2}$ を越える大規模 な敷地の改変により緑被が急激に減少するパターンである。

前者は都市化の進展にとあない敷地が細分化されたあのであり， 緑被が細切れになりつつも比較的残存する形態をとる。

これに対して後者の場合には緑被が大きく消滅，もしくは減少 するものであり，建築形態や土地利用が変化することにより緑被 が急激に減少したものである。特に，本調查地の場合，沿岸付近 ということもあり，土地利用が住居系から観光・レクリエーショ ン・リゾート施設などへの商業系の施設への変化がみられ，こう した場合に緑被が大きく消滅もしくは減少することがわかった。 また，住居系であっても，リゾートマンション等の中高層建築の 建設により緑被は急激に減少している状況が捉えられた。

このように，かつては保養のための別荘地開発が中心で，景観 の保全や育成にも配慮され，良好な住宅地の整備がはかられてい たのに対し，最近では土地利用の変化のみならず敷地の改変がみ られる一方，それらに関連した，緑化等の配慮や施策が不十分で あると考えられる。

\section{4. おわりに}

首都近郊沿岸域である神奈川県逗子市新宿地区において住居系 市街地における緑被の保全について検討するための基礎資料を得 ることを目的に研究した。

緑被の変遷，すなわち緑の減少および消隇には敷地の細分化と 建築形態や土地利用の変化が大きく影響することがわかった。

特に, $1500 \mathrm{~m}^{2}$ を越えるような規模で観光・レクリエーション・ リゾートにかかわる集合住宅・商業系土地利用に転用される場合 がありこうした際には多くの緑被が消滅もしくは減少していた。 以上の状況から，本地域における緑被の保全の問題点および今 後の方策を考えると，まず，都市計画上の用途地域指定変更に伴 う土地利用規制や敷地改变に対する制限等を加えることがあげら れる。

しかしながら，別荘地として開発された本調查地においてはこ うした観光・レクリエーション・リゾートのための土地利用転換 等の要望むあるものと考えられ，それを考慮すれば，開発行為の 際における緑被の保全・緑化を強化する施策の必要があると考え られる。

本研究は空中写真によるデー夕解析を基に，時系列的に緑被の 減少と敷地の変化との関連性を捉え, 本調査地における緑地保全 上の問題点を指摘し，考察を加えた。

なお，本調査地整備の最終的な結論を得るには，ヒヤリング, ワークショップ，アンケート等による地域社会的解析も行う必要 性があるものと考えられる。

\section{参考文献}

1）大森基 (1977)：宅地規模と庭木の実 体に関する研究，昭和 52 年第 12 回 日本都市計画学会学術研究発表論文集 p157 162

2 ）田代順孝・渡辺輝明（1978）：宅地の 利用制御のための基礎的研究，昭和 53 年第 13 回日本都市計画学会学術研 究発表論文集, $p 49 \sim 54$
3）田代順孝（1979）: 住宅地の緑化に関 する計画論的研究，公園緑地 Vol.40 No.3, p62 71

4 ）田代順孝（1983）: 住宅敷地の緑被有 効空地に関する考察, 昭和 58 年第 18 回日本都市計画学会学術研究発表論文 集, p109 114

5 ) 平野㑆三 (1979): 都市環境と緑化率 に関する計画論的研究，緑地学研究，
No.7, pp76

6 ）高見敬志 (1979）：独立住宅地の密度 之居住環境に関する計画技法的研究, 昭和 54 年第 14 回日本都市計画学会学 術研究発表論文集, p247 252

7 ）近江慶光・島田正文・丸田頼一(1995)： 神奈川県藤沢市鵠沼地区における緑の 変遷と保全に関する研究，ランドスケー プ研究, 58(5), p269 272

Summary: In this study, the change and conservation of green coverage at the housing site were investigated at the residential area in Zushi City, Kanagawa. We surveyed the change of green coverage and housing site by the analysis of aerial photographs. The results are as follows;

1) In 1946, there were large-scale sites, these area over $400 \mathrm{~m}^{2}$, built as the villa area. And the tree-covered ratio was $55.7 \%$.

2) But it decreased when the site was divided. The tree-covered ratios were $37.7 \%$ in $1963,18.8 \%$ in $1977,23.7 \%$ in 1988 and $17.2 \%$ in 1992

3) Some residential houses turned to commercial and recreational uses that, there were few green coverage.

It is necessary to establish a new systems to landscape planting. 